\title{
MUSCLE STRENGTH AND ELECTRICAL ACTIVITY, HEART RATE AND ENERGY COST DURING ISOMETRIC CONTRACTIONS IN DISABLED AND NON-DISABLED ${ }^{1}$
}

\author{
By Hans Stoboy \\ Orthopadische Klinik und Poliklinik der Freien Universität Berlin \\ im Oskar-Helene-Heim, I Berlin 33, Clayallee 229/233 \\ and \\ BRYAN WILSON-RICH \\ 165 East 32nd Street, New York, N.Y. I00I6
}

\section{INTRODUCTION}

A COMMON method for determining the degree of physical fitness of an individual is to have him perform with increasing workloads on a bicycle ergometer until his maximal workload is reached.

A comparison between workload (watts or $\mathrm{kg}$. $/ \mathrm{sec}$.) and several parameters of the cardiovascular and respiratory system (i.e. heart rate, $\mathrm{O}_{2}$ consumption, respiratory volume, $\mathrm{O}_{2}$ pulse, etc.) then permits judgment as to the physical fitness of a healthy subject or a patient (Mellerowicz, 1962).

It is a well-known fact that the heart rate of a well-trained subject is significantly less than that of a subject without physical activity.

The physical disability of many patients in Rehabilitation Centres is such that they are unable to perform on an ergometer. This is especially true of many hemiplegics, paraplegics and bilateral amputees. However, these patients are able to propel wheelchairs up to 4.5 miles per day.

It can be assumed that the muscles of the upper extremities are well adapted.

In our earlier investigations using isometric training we found in healthy subjects and in patients with muscular atrophy due to disuse that the electrical activity decreased during the course of training (Friedehold et al., 1958, 1959). This decline in electrical activity with increasing strength depends on a decreasing number of simultaneously excited motor units or a lower discharge frequency of action potentials in the single motor units.

Investigations with needle electrodes showed that a change in discharge frequency occurred only at the beginning of training.

Therefore, the decline in electrical activity must be due mainly to a desynchronisation of simultaneously contracting motor units (Stoboy et al., 1959).

For this reason, during our present investigations we used the integrated electrical activity measured during short isometric contractions as a criterion of the level of physical fitness of disabled subjects.

1 This study was partially supported by Grant No. CD 0003 I-Io from the U.S. Department of Health, Education and Welfare, and supported in part by the Social and Rehabilitation Service, Department of Health, Education and Welfare, under the designation of New York University as a rehabilitation research and training centre. 


\section{MATERIALS AND METHODS}

The following groups were investigated: (I) ten healthy subjects (age 23 to 45 years) without any planned daily activities; (2) seven patients: two paraplegics and five amputees (ages 42 to 63 years) who propelled wheelchair 4.5 miles per day.

All subjects performed three isometric contractions of Io sec. each using the flexors of the right forearm: one contraction of maximum strength; one contraction of approximately two-thirds maximum strength and one contraction of approximately one-third maximum strength.

During a 5-minute rest period, and each contraction phase which is followed by a recovery period of a duration sufficient to permit return of the heart rate to resting values, the following values were recorded or calculated:

I. Muscle Strength. The subject pulled with his right forearm against a strength transducer at an angle between $85^{\circ}$ and $95^{\circ}$.

2. Integrated Electrical Activity. The action potentials of the biceps muscle during contraction were picked up by surface electrodes, rectified electronically and then integrated.

3. Heart rate was calculated from a recorded ECG.

4. $\mathrm{CO}_{2}$ content in expired air was recorded by means of infrared absorption using the capnograph.

5. The $\mathrm{O}_{2}$ content in the expired air was measured with the Oxytest which utilises the paramagnetic characteristic of $\mathrm{O}_{2}$.

6. Respiratory minute volume was measured with a gas meter, and from the last two values $\mathrm{O}_{2}$ consumption was calculated. In the measurement of the $\mathrm{O}_{2}$ consumption the $\mathrm{O}_{2}$ dept was included.

Throughout the recording, the room temperature was kept between $22^{\circ}$ and $24^{\circ} \mathrm{C}$.

\section{RESULTS}

x. The ranges of maximum strength were distinctly different for the normals and the disabled (2I to $27.5 \mathrm{~kg} ; 34$ to $39 \mathrm{~kg}$. respectively). In both groups the electrical activity is almost linearly correlated to muscle strength $(r>0.9)$.

The highest values can be seen in the disabled group due to their higher maximum strengths. In the range of two-thirds maximum strength, the values of the electrical activity of disabled are significantly different from those of normals $(\mathrm{P}<0.005)$ (fig. I).

2. The maximal heart rate of the disabled is distinctly lower than in normals (92 to 104; 106 to 124 respectively) in spite of higher strength.

The same relationship is also evident in the range of two-thirds maximum strength with an $\mathrm{P}>0.005$.

There is some overlap for the values at rest (fig. 2).

3. The $\mathrm{O}_{2}$ consumption of the disabled as compared to the normals appears to be lower over the total range of strength. However, the difference for the maximal $\mathrm{O}_{2}$ consumption is very small (Io $\mathrm{ml}$.; $5 \mathrm{ml}$. respectively). In the range of two-thirds maximum strength no statistical difference could be found $(\mathbf{P}>0.5)$ (fig. 3).

4. Energy cost of isometric contractions is very small. The maximal values 

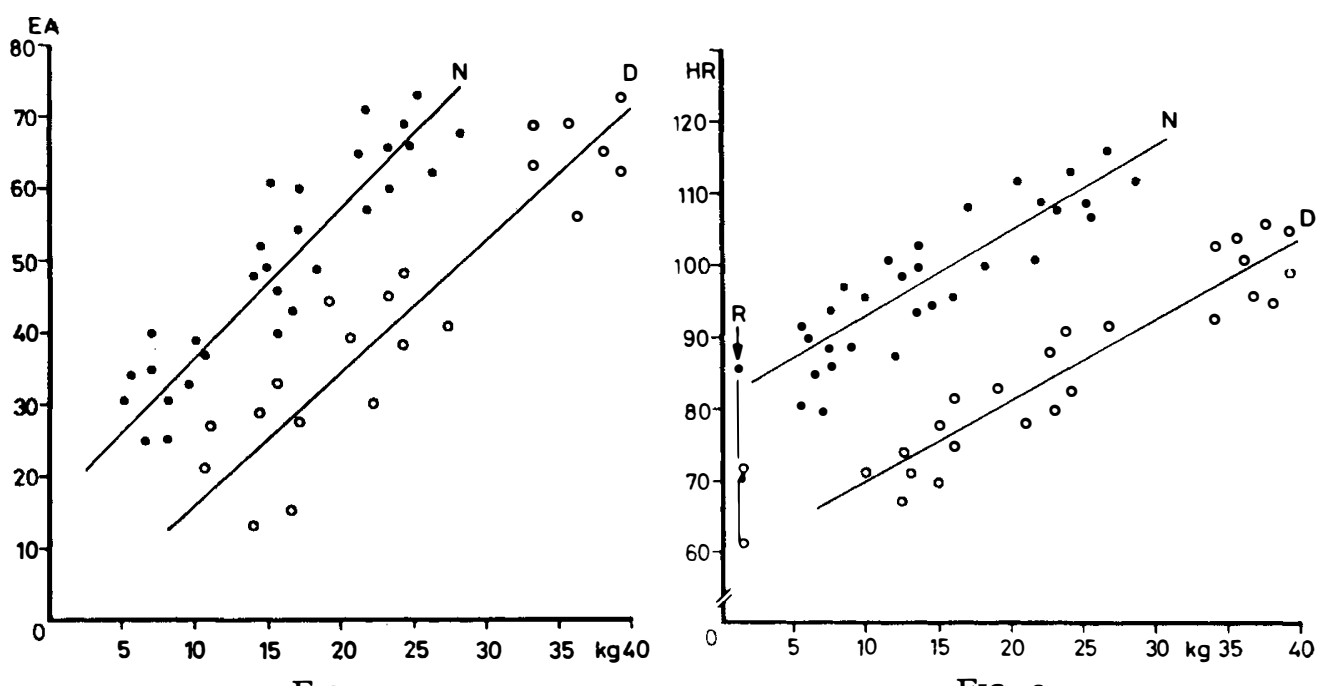

FIG. I

FIG. 2

Fig. I.-Relationship between Electrical Activity and Strength for Normal (No) and Disabled (Do) Subjects.

Fig. 2.-Relationship between Heart Rate and Strength for Normal (No) and Disabled (Do) Subjects.

Fig. 3.-Relationship between $\mathrm{O}_{2}$ Consumption and Strength for Normal (No) and Disabled (Do) Subjects.

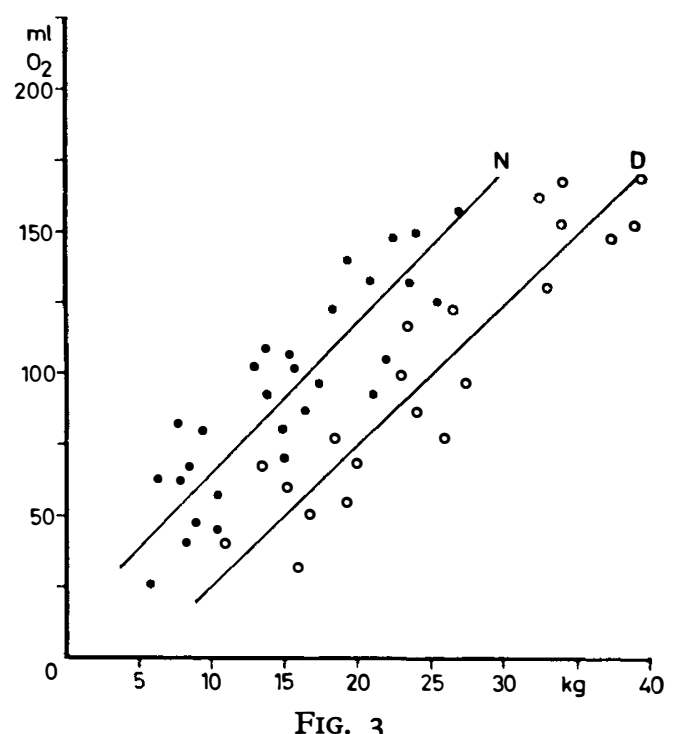

FIG. 3 
$(0.74$ and $0.78 \mathrm{kcal}$.) and average values $(0.36$ and 0.34$)$ are nearly identical in the normals and disabled. No statistical difference could be detected.

TABLE I

Energy Cost Values for Normal and Disabled Subjects during Isometric Contractions

\begin{tabular}{|c|c|c|c|c|c|}
\hline & $\begin{array}{l}\text { Heart } \\
\text { rate }\end{array}$ & $\begin{array}{l}\text { Total } \mathrm{O}_{2} \\
\text { consumption } \\
\text { (ml./min.) } \\
\text { STPD }\end{array}$ & $\begin{array}{c}\text { Netto } \mathrm{O}_{2} \\
\text { consumption } \\
\text { for isometric } \\
\text { contractions } \\
\text { (ml./min.) } \\
\text { STPD }\end{array}$ & $\begin{array}{l}\text { Brutto } \\
\text { energy cost } \\
\text { (kcal.) }\end{array}$ & $\begin{array}{l}\text { Netto } \\
\text { energy cost } \\
\text { for the } \\
\text { isometric } \\
\text { contraction } \\
\text { (kcal.) }\end{array}$ \\
\hline $\begin{array}{l}\text { Normal } \\
\text { Average } \\
\text { Maximum }\end{array}$ & $\begin{array}{l}\text { I03 } \\
\text { I } 24\end{array}$ & $\begin{array}{l}355 \\
430\end{array}$ & $\begin{array}{r}75 \\
150\end{array}$ & $\begin{array}{l}\text { I.72 } \\
2 \cdot \text { I I }\end{array}$ & $\begin{array}{l}0.36 \\
0.74\end{array}$ \\
\hline $\begin{array}{l}\text { Disabled } \\
\text { Average } \\
\text { Maximum }\end{array}$ & $\begin{array}{r}88 \\
104\end{array}$ & $\begin{array}{l}360 \\
445\end{array}$ & $\begin{array}{r}70 \\
160\end{array}$ & $\begin{array}{l}I \cdot 75 \\
2 \cdot 2 I\end{array}$ & $\begin{array}{l}0.34 \\
0.78\end{array}$ \\
\hline
\end{tabular}

\section{DISCUSSION}

The values of maximal strength of our normals compare well with those reported by Hettinger (1966). Therefore, the maximal strength of our disabled patients is increased considerably. According to Inman (1952) and Lippold (1952) the electrical activity is linearly correlated to muscular strength in acute experiments. As has been shown the electrical activity decreases during progressive isometric training in normal and atrophied muscles (Friedebold et al., 1957, 1959). Experiments with needle electrodes have pointed out, that this decrease is due primarily to a desynchronisation of simultaneously contracting motor units (Stoboy, 1959). During the course of training increasing loads can be held with a smaller number of synchronously contracting motor units. Therefore, we assumed that in the same range of strength, disabled subjects, trained to propel wheelchairs, have a lower electrical activity than the normals. This was shown with a high degree of significance in the present investigation. The same relationship between maximum strength and electrical activity was reported by De Vries (1966). In trained subjects with a large maximum strength, the electrical activity at the same strength was significantly less than in untrained subjects.

The highest heart rates during maximal isometric contractions are in good agreement with those reported by Lind and McNicol (1967). It is well known that the heart rate for the same workload decreases with increasing physical fitness in ergometric tests. We found the same relationship between our two groups, and nearly the same difference can be found in the resting values. This means that the percentages of increase in heart rate is the same for both groups $(\approx+60$ per cent.).

For the $\mathrm{O}_{2}$ consumption of the two groups no statistical difference could be 
found. Our $\mathrm{O}_{2}$ consumption values approximate those of Josenhans (1967), who measured for isometric contractions of approximately 30 per cent. maximum strength for a duration of $150 \mathrm{sec}$. ( $2 \mathrm{I} \mathrm{ml.} \mathrm{O}_{2} / \mathrm{sec}$.).

The energy cost of isometric contractions is relatively low (av. $\mathrm{I} \cdot 72 \mathrm{kcal}$.; max. 2.2I kcal.).

These values are equivalent to those reported by Lehmann (I962): (I) descending a $10^{\circ}$ decline at $5 \mathrm{~km}$. $/ \mathrm{hr}$. $=\mathrm{I} \cdot 8 \mathrm{kcal} . / \mathrm{min}$.; (2) milking cows at the rate of $4.2 \mathrm{ml}$. per squeeze $=2 \cdot 2 \mathrm{kcal}$. $/ \mathrm{min}$; (3) undressing and dressing $=2 \cdot 0$ to $3.0 \mathrm{kcal} . / \mathrm{min}$.

Our increase in heart rate during maximum isometric contraction corresponds to data collected by Hollmann (1958), Reindell et al. (1956, 1962) and Mellerowicz (I962) at steady-state workloads between 50 and 70 watts.

But our $\mathrm{O}_{2}$ consumption values for isometric contractions with maximum strength correspond to the data collected by Lehmann (1962), Reindell et al. (I962) and Mellerowicz (I962) a steady-state workloads of Io to I5 watts.

A workload of Io to I 5 watts corresponds to a heart rate of approximately 85 to 95 (Bentsson, 1956) so that the maximal heart rates in this investigation exceed steady state values by 15 to 40 beats.

This additional increase in heart rate cannot be accounted for by a partial Valsalva manoeuvre which occurs during a maximal strength contraction, because heart rate increases only slightly ( 5 to io beats) during a maximal Valsalva manoeuvre of Io sec. duration (Marshall et al., I96I).

As to the reason for the additional increase in heart rate it is probably due to a prior cortical adjustment of circulation as found by Stoboy and Nüssgen (1956) in humans and Wittke and Haberich (1958) in race-horses. In these investigations the heart rate was enhanced distinctly in anticipation of the following motoric event by attention. The heart rate of a girl attending a beat concert varied between I 20 and I 50, although it was presumed that the $\mathrm{O}_{2}$ uptake was low (Astrand, I967). The time of Io sec. is probably too short for a reflex increase of heart rate caused by $\mathrm{PCO}_{2}$ receptors in muscle as assumed by Stegemann (1963).

Possibly the concept of 'anticipatory heart rate' should be explored.

The measurement of this investigation indicates that short isometric contractions can be used to determine physical fitness and the degree of adaptation in patients not able to use a normal ergometer.

\section{SUMMARY}

This investigation was designed to determine the degree of adaptation of disabled subjects to a permanent wheelchair existence and the following parameters were studied: strength of the $\mathrm{m}$. biceps femoris, integrated electrical activity of $\mathrm{m}$. biceps femoris, heart rate, $\mathrm{O}_{2}$ consumption, $\mathrm{CO}_{2}$ output, and energy expenditure. It was found, that heart rate and electrical activity were lower at any level of strength in the disabled group so that it can be assumed that wheelchair-bound subjects are adapted to their disability. 


\section{RÉSUMÉ}

D'après les différents paramètres utilisés pour l'étude de l'adaptation du handicapé à sa chaise roulante, il se révèle que l'handicapé en chaise roulante est adapté à son handicap.

\section{ZUSAMMENFASSUNG}

Der Zweck dieser Untersuchung war, den Grad der Adaptation von Körperbehinderten zu eninem Leben im Rollstuhl zu bestimmen und folgende Parameter wurden studiert: Stärke und elektrische Akivität des Bisceps femoris, Herzfrequenz, $\mathrm{O}_{2}$ und $\mathrm{CO}_{2}$ Austausch und Energieverbrauch. Auf Grund der Ergebnisse kann angenommen werden, dass an Rollstuhl gebundene Patienten an ihre Körperbehinderung adaptiert sind.

Acknowledgment. We want to thank M. Smodlaka and E. Griffin for technical assistance and F. Trainor Ph.D., for organisatory help.

\section{REFERENCES}

Åstrand, P. O. (1967). Canad. Med. Ass. F. 96 (March), 907-9I I.

Bengtsson, E. (I956). Acta Med. Scand. I 54 (June), 9I-IO9.

FRIEDEBOLD, G., NüssGeN, W. \& Stoboy, H. (1957). Zeitschrift für die gesamte experimentelle Medizin, 129, (Sept.), 40I-4I I.

Friedebold, G., Stoboy, H. \& NǘssGen, W. (1959). A. Orthop. u. Grenzgebiete, 9I (July), 79-87.

HetTINGER, TH. (1966). Isometrisches Muskeltraining, p. 22. Stuttgart, Germany: Georg Thieme.

Hollmann, W. (1958). Der Arbeits- und Trainingseinflu $\beta$ auf Kreislauf und Atmung, pp. 28-46. Darmstadt, Germany: Dr. Dietrich Steinkopff.

INMAN, V. T. et al. (1952). Neurophysiol. 4, (May) I87-194.

Josenhans, W. T. (I967). Canad. Med. Ass. $\mathcal{F . ~} 96$ (March), 76I-763.

Lehmann, G. (1962). Praktische Arbeitsphysiologie, pp. I35-I54. Stuttgart, Germany: Georg Thieme.

Lind, A. R. \& McNicol, G. W. (1967). Canad. Med. Ass. F. 96 (March), 706-7ir3.

Lippold, O. C. J. (1952). F. Physiol. 177 (Aug.), 492-499.

MARSHALl, R. J., SCHIRGER, A. \& SHEPHERD, J. T. (I96I). Circulation, 24 (July), 76-8I.

MellerowiCZ, H. (1962). Ergometrie, pp. 5I-70. Mūnchen-Berlin, Germany: Urban and Schwarzenberg.

ReINDELl, H. \& KirchHoff, H. W. (1956). Dtsch. Med. Wscher. 8I (June), I048-I053.

ReINDEll, H., RosKamm, H. \& GerschleR, W. (I962). Das Intervalltraining, pp. 34-42. München, Germany: Johann Ambrosius Barth.

Stegemann, J. (1963). Pflügers Archiv. 276 (Nov.), 5 I I-524.

Stoboy, H. \& NüssGEN, W. (I956). Zeitschrift für Kreislaufforschung, 45 (May), 82-83.

Stoboy, H., Nüssgen, W. \& FrIedebold, G. (1959). Int. Z. angew. Physiol. einschl. Arbeitsphysiol. 17 (May), 391-399.

VRIEs, De H. A. (1966). Physiology of Exercise, pp. 313-315. Dubuque, Iowa: W. M. C. Brown.

WitTKe, G. \& HABERICH, F. J. (I958). Zeitschrift für Biologie, IIO (July), 280-284. 